\title{
Pewilayahan Komoditas Pertanian Berdasarkan Zona Agroekologi Skala 1: 50.000 Di Kabupaten Batanghari Jambi
}

\author{
Busyra Buyung Saidi ${ }^{1)}$ dan Erna Suryani ${ }^{2)}$ \\ ${ }^{1)}$ Peneliti Balai Pengkajian Teknologi Pertanian Jambi \\ 2) Peneliti Balai Besar Litbang Sumberdaya Lahan Bogor \\ e-mail: busyra_sidi@yahoo.co.id \\ Mobile: 08127866061
}

\begin{abstract}
ABSTRAK
Penelitian pewilayahan komoditas pertanian berdasarkan Zona Agroekologi (ZAE) skala 1:50.000 di Kabupaten Batanghari, bertujuan: mengidentifikasi potensi sumberdaya lahan untuk pengembangan pertanian; menyusun informasi tipe penggunaan lahan untuk sistem pertanian yang tepat; menyusun peta pewilayahan komoditas pertanian berdasarkan ZAE skala 1:50.000. Penelitian dilakukan dengan pendekatan desk study, observasi dan survei. Hasil penelitian menunjukkan bahwa wilayah Batanghari mempunyai tipe iklim tergolong A dengan nilai $\mathrm{Q}<14,3 \%$, mempunyai bulan basah (curah hujan $>100 \mathrm{~mm} /$ bulan) rata-rata selama 12 bulan. Hasil analisis landform menunjukkan bahwa Kabupaten Batanghari terdiri atas grup Aluvial, Volkan, dan Tektonik/Stuktural. Bentuk wilayah 44,01\% merupakan relief bergelombang, dengan lereng 8-15\%.. Hasil identifikasi peta tanah dan verifikasi lapangan menunjukkan bahwa kabupaten Batanghari terdiri atas 30 Satuan Peta Tanah, jenis tanah digolongkan ke dalam 4 ordo tanah, yaitu: Histosol, Inceptisols, Ultisols dan Oxisols. Pewilayahan komoditas pertanian ditetapkan dengan 4 sistem pertanian, yaitu sistem pertanian lahan basah untuk tanaman padi sawah, palawija dan sayuran (Zona IV/Wr dan IV/Wrh), pertanian lahan kering tanaman pangan dan hortikultura (Zona IV/Dfh-1, IV/Dfh-2, IV/Dfh-3, dan IV/Dfeh-4); pertanian lahan kering, tanaman tahunan berbasis tanaman pangan (Zona III/Defh-1 dan III/Defh-2), pertanian lahan kering tanaman tahunan/perkebunan (ZonaII/Deh).
\end{abstract}

Kata kunci : Zona agroekologi, komoditas pertanian, pewilayahan komoditas..

\section{PENDAHULUAN}

Sejalan dengan meningkatnya jumlah penduduk yang cukup besar di Indonesia menyebabkan meningkatnya kebutuhan lahan untuk berbagai keperluan termasuk untuk memproduksi bahan pangan, serat dan papan. Tekanan penduduk yang besar dan meningkatnya pertumbuhan ekonomi dan industri menimbulkan kompetisi penggunaan lahan di berbagai sektor yang tidak terkendali, termasuk sektor pertanian. Hal ini menekankan perlunya perencanaan dan pengelolaan sumberdaya lahan yang rasional dan berkelanjutan sesuai dengan daya dukungnya.

Dalam usaha mendukung perencanaan penggunaan lahan yang sesuai dengan daya dukungnya, FAO sekitar tahun 1978 telah memperkenalkan konsep penyusunan Peta Zona AgroEkologi (Agro-Ecological Zone) untuk membantu perencanaan dan pengelolaan lahan pertanian terintegrasi untuk negara-negara berkembang di Afrika, Asia dan Amerika Latin. Selama lebih dari dua dekade FAO telah mengembangkan dan mengaplikasikan pendekatan metode AEZ mendukung perencanaan dan pengelolaan lahan untuk pengembangan pertanian yang berkelanjutan pada tingkat nasional, dan provinsi (FAO, 1996) 
Sampai tahun 2014, Badan Litbang Pertanian melalui Balai Besar Litbang Sumberdaya Lahan Pertanian (BBSDLP) telah menghasilkan data dasar tanah melalui kegiatan pemetaan tanah tingkat tinjau (skala 1:250.000) seluruh wilayah Indonesia. Sesuai dengan skalanya, informasi yang terkandung di dalam peta tersebut hanya tepat digunakan untuk perencanaan pembangunan pertanian di tingkat provinsi/regional. Sedangkan untuk keperluan perencanaan di tingkat kabupaten/kota diperlukan data karakteristik tanah dan potensi sumberdaya lahan dalam skala yang lebih operasional, yaitu skala 1:50.000 atau lebih besar. Oleh sebab itu tahun 2015 Balai Pengkajian Teknologi Pertanian Jambi berupaya melengkapi peta tanah pada skala yang lebih besar skala 1:50.000.

Dalam usaha meningkatkan daya guna dan pemanfaatan data yang ada diperlukan cara penyajian informasi secara geospasial, yang dapat membantu memberikan bahan pertimbangan pengambilan kebijakan pembangunan pertanian di daerah. Salah satu alternatif penyajian informasi geospasial adalah pendekatan zona agroekologi, yang mengintegrasikan data tanah, iklim dan terrain (Amien 2011). Pendekatan tersebut mengelompokkan lahan kedalam satuan-satuan lahan berdasarkan kemiripan karakteristik iklim, terrain dan tanah, yang mempunyai potensi sumberdaya lahan yang sama

Konsep pewilayahan pertanian atau pemetaan zona agroekologi (ZAE) adalah penyederhanaan dan pengelompokan agroekosistem yang beragam dalam bentuk klasifikasi yang lebih aplikatif (Las et al., 1990). ZAE juga merupakan salah satu metode pengidentifikasian lahan yang digunakan untuk tanaman tertentu yang berpotensi tinggi dengan memperhatikan aspek-aspek agroekosistem atau sumberdaya alam yang terdiri atas tanah, iklim dan vegetasi.

Pewilayahan komoditas pertanian berdasarkan ZAE skala 1:50.000 di Kabupaten Batanghari bertujuan: (1) mengidentifikasi potensi sumberdaya lahan untuk pengembangan pertanian; (2) menyusun informasi tipe penggunaan lahan untuk sistem pertanian yang tepat sebagai dasar pembangunan pertanian berkelanjutan; (3) menyusun peta pewilayahan komoditas pertanian berdasarkan ZAE skala 1:50.000. Hasil penelitian ini diharapkan dapat bermanfaat : (1) dasar perencanaan pembangunan pertanian yang efektif dan berkelanjutan.; (2) memudahkan dalam menetapkan kawasan-kawasan pengembangan komoditas unggulan; (3) memudahkan dalam memilih paket teknologi yang sesuai untuk tiap-tiap kawasan tertentu atau ekstrapolasi teknologi yang telah teruji yang kondisi fisik lingkungan dan sosial ekonominya sama atau hampir sama.

\section{BAHAN DAN METODE}

Bahan yang digunakan terdiri atas: peta rupabumi digital skala 1:25.000 (Bakosurtanal, 1998); citra landsat TM skala 1:60.000 (1998); peta geologi skala 1:250.000 lembar Muaro Bungo (Puslitbang Geologi, 1994); peta agroekologi utama tanaman pangan di Indonesia (Las, et al. 1991); Atlas Sumberdaya Iklim Pertanian Indonesia skala 1:1.000.000 (Balitklimat dan Hidrologi, 2003) dan Peta Tanah Tinjau Kabupaten Batanghari (Balittanah, 
2003). Penelitian dilakukan dengan pendekatan desk study dan survei. Penyusunan peta kerja melalui analisis terrain foto udara/Citra landsat, digitasi dan overlay peta rupabumi. Peta kerja digunakan sebagai dasar karakterisasi tanah. Survei tanah mengacu pada Petunjuk Teknis Survei dan Pemetaan Tanah Tingkat Semi Detail Skala 1:50.000 (Hikmatullah et al. 2014). Survei sosial ekonomi dilakukan dengan teknik wawancara dengan petani di sentra produksi dan daerah potensial pengembangan (BBSDLP, 2011).

Analisis contoh tanah dilakukan di laboratorium Balai Penelitian Tanah, Bogor, meliputi: penetapan tekstur (3 fraksi), kandungan bahan organik $(\mathrm{C}, \mathrm{N}$, dan $\mathrm{C} / \mathrm{N}$ ), reaksi tanah (pH $\mathrm{H} 2 \mathrm{O}$ dan $\mathrm{pH} \mathrm{KCl}$ ), kandungan $\mathrm{P} 2 \mathrm{O} 5$ dan $\mathrm{K} 2 \mathrm{O}$ potensial (ekstraksi $\mathrm{HCl} 25 \%$ ), P2O5Olsen dan Bray I, basa-basa dapat tukar (Ca, Mg, K, dan $\mathrm{Na}$ ), kapasitas tukar kation (KTKNH4OAc $\mathrm{pH}$ 7), kemasaman dapat tukar ( $\mathrm{Al}$ dan $\mathrm{H}$ ) ekstrak $\mathrm{KCl} 1 \mathrm{~N}$ dan komposisi mineral pasir fraksi total. Prosedur analisis contoh tanah mengacu pada Petunjuk Teknis Analisis Kimia Tanah, Air, Tanaman, dan Pupuk (Eviati dan Sulaeman 2012). Data sosial ekonomi dianalisis dengan analisis B/C ratio, Net Present Value (NPV), dan Internal Rate of Return (IRR) (Kadariah, 1988). Evaluasi lahan dilakukan dengan pendekatan two stages approach, menggunakan program ALES (Automated Land Evaluation System) (Rossiter dan Van Wambeke, 1997). Pengelompokan kelas kesesuaian lahan menurut BBSDLP. 2011. Dengan menggunakan program modul pewilayahan komoditas (MPK) disusun pewilayahan komoditas pertanian (Bachri, et al. 2002). Slanjutnya untuk melihat kesesuaian hasil analisis dengan kondisi di lapangan dilakukan verifikasi dan validasi.

\section{HASIL DAN PEMBAHASAN}

\section{Karakteristik Biofisik}

Kabupaten Batang Hari dilintasi garis khatulistiwa dan terletak pada $1^{\circ} 23^{\prime} 2^{\circ} 23^{\prime}$ Lintang Selatan dan $102^{\circ} 29^{\prime}-103^{\circ} 28^{\prime}$ Bujur Timur. Berbatasan di timur dengan Kabupaten Muaro Jambi; di barat dengan Kabupaten Tebo; di utara dengan Kabupaten Tebo, Kabupaten Muaro Jambi, dan Kabupaten Tanjung Jabung Barat; di selatan dengan Provinsi Sumatera Selatan, Kabupaten Sarolangun dan Kabupaten Muaro Jambi. Secara umum kabupaten ini berada pada hamparan wilayah dataran rendah dengan ketinggian tempat 11-500 $\mathrm{m}$ dpl. Agroekosistem dominan adalah lahan kering.

Berdasarkan distribusi curah hujan bulanan dan dibandingkan dengan kriteria penentuan nilai Q yang dikemukan oleh Schmidt dan Ferguson (1951) bahwa semua wilayah Batanghari mempunyai tipe iklim tergolong A dengan nilai $\mathrm{Q}<14,3 \%$. Kabupaten ini mempunyai bulan basah (curah hujan $>100 \mathrm{~mm} / \mathrm{bulan}$ ) rata-rata selama 12 bulan. Hal ini menunjukkan bahwa kabupaten Batanghari merupakan wilayah yang sangat basah. Berdasarkan penyebaran rata-rata curah hujan bulanannya, Batanghari mempunyai pola hujan tergolong A menunjukkan terjadi perbedaan yang nyata antara curah hujan di musim hujan dengan curah hujan di musim kemarau. 
Zona Agroklimat Kabupaten Batanghari menurut Peta Agroklimat Sumatera skala 1:3.000.000 (Oldeman, et al, 1979) termasuk ke dalam zona agroklimat $\mathrm{B}_{1}$. Zona ini memberikan gambaran bahwa bulan-bulan basah (curah hujan $>200 \mathrm{~mm}$ ) terjadi selama 7-9 bulan berturut-turut dan bulan kering (curah hujan $<100 \mathrm{~mm}$ ) terjadi $<2$ bulan berturut-turut.

Curah hujan rata-rata bulanan di kabupaten Batanghari adalah $206.87 \mathrm{~mm}$ dengan jumlah hari hujan 14.04 hari, dengan suhu rata-rata bulanan $26.42^{\circ} \mathrm{C}$ dan Kelembaban $26.45 \%$ (BPS, 2016). Curah hujan bulanan tertinggi diatas $200 \mathrm{~mm} / \mathrm{bulan}$, terjadi pada bulan November sampai April, sedangkan curah hujan bulanan di bawah $200 \mathrm{~mm}$ terjadi pada bulan Mei sampai Oktober (Gambar 1).

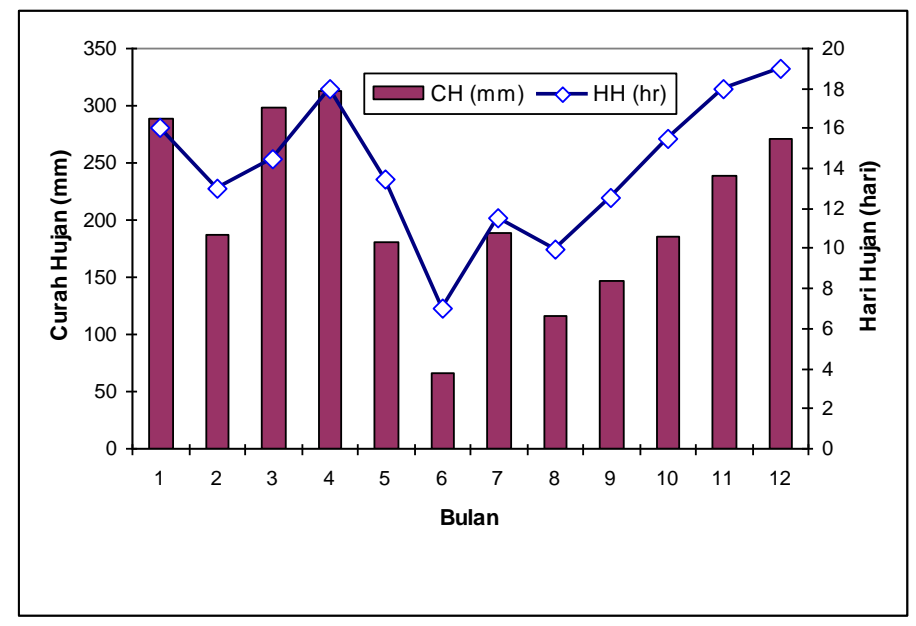

Gambar 1. Pola curah hujan di Kabupaten Batang Hari (2005-2014)

\section{Landform dan Relief}

Berdasarkan peta geologi bersistem Indonesia lembar Sarolangun (0913) (Puslitbang Geologi 1992) dan Muara Bungo (0914), Sumatera skala 1:250.000 (Puslitbang Geologi, 1994) bahwa Kabupaten Batanghari dibentuk oleh formasi geologi berumur kuarter yang terdiri atas aluvium (Qa), endapan rawa (Qs), dan formasi geologi berumur tersier yang terdiri atas formasi Kasai (QTk), formasi Muaraenim (Tmpm), formasi Air benangat (Tma), formasi Gumai (Tmg), formasi Talangakar (Tomt), formasi lahat, formasi Terantam (Ct), dan batuan Pegmatit (Jpg).

Landform Kabupaten Batanghari dapat dikelompokkan dalam 3 group fisiografi utama yaitu Aluvial (A), Volkanik (V), dan Tektonik/Stuktural (T). Secara rinci jenis dan sebaran landform di Kabupaten Batanghari disajikan pada Tabel 1. 
Tabel 1. Sebaran landform di Kabupaten Batanghari, Jambi

\begin{tabular}{|c|c|c|c|c|}
\hline \multirow{2}{*}{ Grup } & \multirow{2}{*}{ Grup Landform } & \multirow{2}{*}{ Satuan Lahan } & \multicolumn{2}{|c|}{ Luas } \\
\hline & & & $\mathrm{Ha}$ & $\%$ \\
\hline \multirow{3}{*}{ Aluvial (A) } & Rawa belakang sungai meander & 1,2 & 43.537 & 7,68 \\
\hline & Bekas tasik sungai & 3 & 208 & 0,04 \\
\hline & Jalur aliran & 4 & 14.033 & 2,48 \\
\hline \multirow[t]{2}{*}{ Volkanik (V) } & Dataran volkanik tua & 5 & 29 & 0,01 \\
\hline & Intrusi volkanik & 6 & 535 & 0,09 \\
\hline \multirow[t]{8}{*}{ Tektonik (T) } & Lereng pemiringan & 7 & 610 & 0,11 \\
\hline & Punggung Antiklin & 8,9 & 71.377 & 12,59 \\
\hline & Depresi Sinklin & $10,11,12,13,14$ & 70.869 & 12,50 \\
\hline & Peneplain datar & 15,16 & 3.004 & 0,53 \\
\hline & Dataran tektonik datar & 17,18 & 32.208 & 5,68 \\
\hline & Dataran tektonik berombak & $19,20,21$ & 104.197 & 18,38 \\
\hline & $\begin{array}{l}\text { Dataran tektonik } \\
\text { bergelombang }\end{array}$ & $22,23,24,25,26$ & 200.256 & 35,33 \\
\hline & Perbukitan Tektonik & $27,28,29,30$ & 24 & 0,00 \\
\hline $\mathrm{X} 3$ & Tubuh air & 333 & 7.791 & 1,37 \\
\hline X6 & Pulau kecil & 666 & 39 & 0,01 \\
\hline Total & & & 566.782 & 100,00 \\
\hline
\end{tabular}

Grup Aluvial (A)

Landform ini merupakan landform muda (resen dan subresen) yang terbentuk akibat proses fluvial (aktivitas sungai), koluvial (gravitasi) atau gabungan kedua proses tersebut (fluvial dan koluvial). Grup aluvial yang dijumpai di Kabupaten Batanghari adalah rawa belakang sungai bermeander, bekas tasik sungai, dan jalur aliran dengan total luas 57.776 ha atau $10,19 \%$ dari luas kabupaten.

Grup Volkanik (V)

Wilayah yang merupakan sistem dari gunung berapi dengan letusan berulang-ulang, sehingga terjadi pelapisan piroklatik dan lairan lava. Grup landform volkanik yang dijumpai di Kabupaten Batanghari adalah intrusi volkanik. Intrusi volkanik adalah wilayah yang terbentuk akibat penerobosan magma melalui celah/retakan/patahan dalam kulit bumi yang mulcul kepermukaan karena ersosi, dijumpai pada wilayah berbukit kecil. Lanform ini mencapai luas 564 ha atau $0,01 \%$ dari luas kabupaten.

Grup Tektonik (T) 
Landform yang terbentuk sebagai akibat deformasi kulit bumi oleh proses angkatan, patahan dan atau lipatan (tektonik). Grup landform tektonik yang dijumpai di Kabupaten Batanghari yaitu: lereng pemiringan, punggung antiklin, depresi antiklin, peneplain datar, dataran tektonik datar, dataran tektonik berombak, dataran tektonik bergelombang, dan perbukitan tektonik. Landform tektonik paling luas dijumpai di Kabupaten Batanghari yaitu 5008.442 ha atau $89,71 \%$ dari luas kabupaten.

Relief dan luas penyebarannya di kabupaten Batanghari disajikan pada Tabel 2. Berdasarkan tabel tersebut kabupaten Batanghari didominasi oleh bentuk wilayah bergelombang, lereng $8-15 \%$ yang mencakup luasan $44,01 \%$ dari luas kabupaten. Bentuk wilayah luas berikutnya adalah berombak, lereng 3-8\% mencapai 20,06\% serta berbukit $18,28 \%$ dari luas kabupaten Batanghari.

Tabel 2. Sebaran bentuk wilayah di Kabupaten Batanghari, Jambi.

\begin{tabular}{|c|c|c|c|c|}
\hline \multirow{2}{*}{ Relief } & \multirow{2}{*}{ Lereng $(\%)$} & \multirow{2}{*}{ Satuan Lahan } & \multicolumn{2}{|c|}{ Luas } \\
\hline & & & $\mathrm{Ha}$ & $\%$ \\
\hline Datar & $0-1$ & $1,3,4$ & 33.471 & 5,91 \\
\hline Agak datar & $1-3$ & $2,5,15,17,18$ & 58.692 & 10,36 \\
\hline Berombak & $3-8$ & $11,16,19,20,21$ & 113.707 & 20,06 \\
\hline Bergelombang & $8-15$ & $10,11,13,22,23,24,25,26$ & 249.447 & 44,01 \\
\hline Berbukit & $15-25$ & $6,7,8,9,14,27,28,29,30$ & 103.635 & 18,28 \\
\hline Tubuh air & & 333 & 7.791 & 1,37 \\
\hline Pulai kecil & & 666 & 39 & 0,01 \\
\hline Jumlah & & & 566.782 & 100,00 \\
\hline
\end{tabular}

\section{Satuan Lahan}

Peta satuan lahan (land unit map) adalah peta yang menggambarkan penyebaran dari satuan-satuan lahan/tanah di suatu wilayah. Satuan lahan adalah unit-unit lahan dengan sifatsifat yang sama atau hampir sama yang berkaitan dengan potensi tanahnya. Komponen peta satuan lahan terdiri dari: satuan sub-landform, satuan bahan induk, satuan relief dan lereng, satuan tanah pada tingkat subgrup, dan keterangan luas.

Satuan tanah yang tercantum merupakan satuan tanah hasil pengamatan di lapangan dan telah dikorekasi dengan hasil analisis laboratorium. Satuan tanah merupakan komponen utama satuan lahan yang dinyatakan dalam klasifikasi tanah sampai tingkat subgrup menurut Soil Taxonomy (Soil Survey Staff, 2014).

Hasil identifikasi peta tanah Semi Detail skala 1:50.000 dan verifikasi lapangan menunjukkan bahwa kabupaten Batanghari terdiri atas 30 Satuan Peta Tanah. Berdasarkan Peta Satuan Lahan dan Tanah, diperoleh bahwa tanah-tanah di kabupaten batabnghari digolongkan ke dalam 4 ordo tanah, yaitu: Histosol, Inceptisols, Ultisols dan Oxisols Tabel 
4).. Pada tingkat yang lebih rendah (Grup) dibedakan menjadi Fluvaquents, Endoaquepts, Dystrudepts, Hapludults, Kandiudults, lohumults, Kandiudox dan Hapludox (Soil Survey Staff. 2014). Diantara tanah-tanah tersebut, Dystrudepts, Kandiudox, Hapludox dan Hapludults merupakan tanah-tanah dominan. Sebaran jenis tanah pada tiap satuan lahan disajikan pada Peta tanah semi detil Kabupaten Batanghari skala 1:50.000 Gambar 2.

Tabel 4. Klasifikasi tanah (Soil Taxonomy, 2014) sampai tingkat Great group di Kabupaten Batanghari.

\begin{tabular}{lll}
\hline Ordo & \multicolumn{1}{c}{ Satuan Tanah } \\
Great Grup & \multicolumn{1}{c}{ Sub Grup } \\
\hline 1. Histosols & Haplohemist & Tipyc Haplohemist \\
2. Inceptisols & Endoaquepts & Typic Endoaquepts \\
& Epiaquepts & Typic Epiaquepts \\
& Dystrudept & Fluventic Dystrudepts \\
& & Typic Dystrudepts \\
& & Oxic Dystrudepts \\
3. Oxisols & Hapludox & Typic Hapludox \\
4. Ultisols & Hapludults & Typic Hapludutls \\
& Kanhapludults & Typic Kanhapludults \\
\hline
\end{tabular}

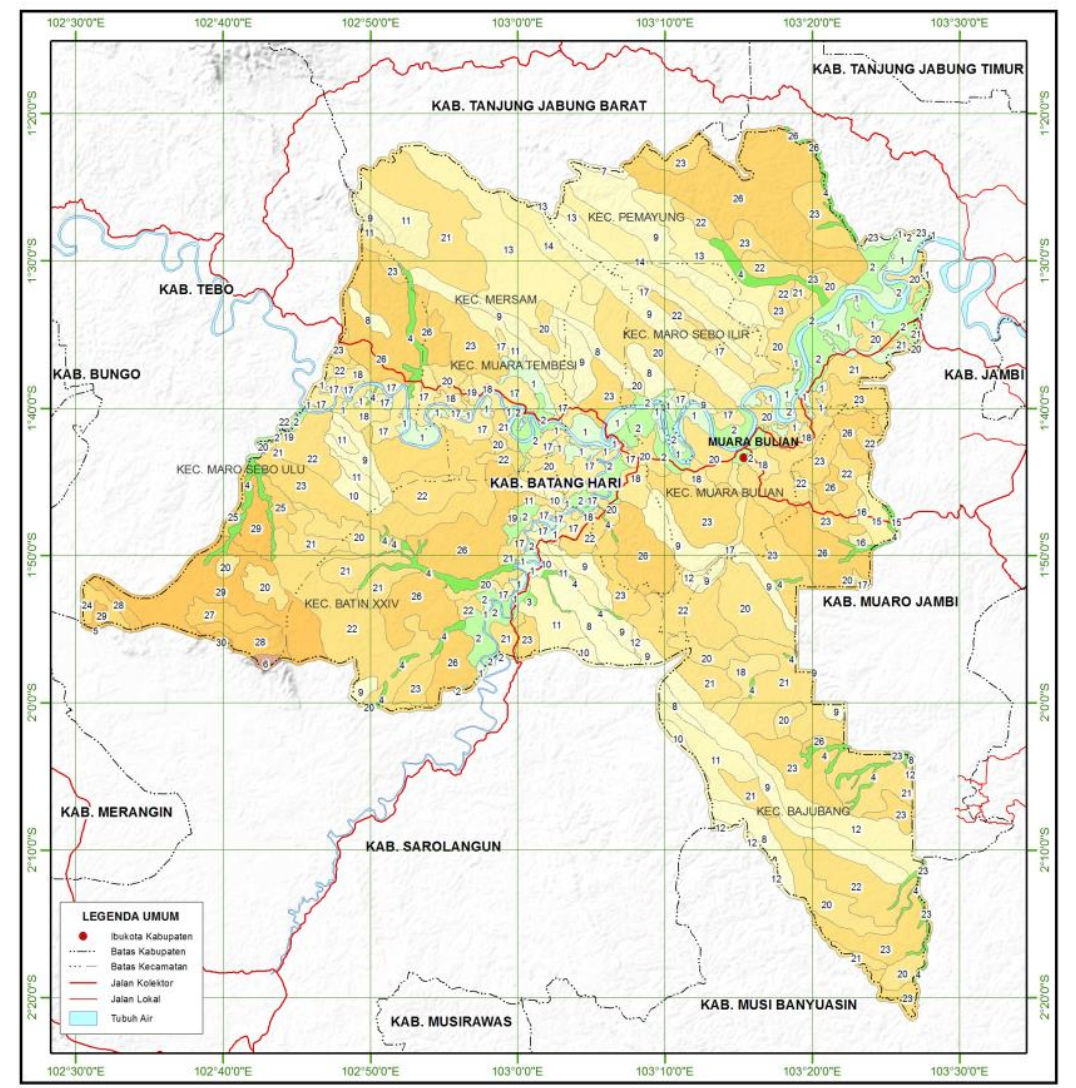

Gambar 2. Peta tanah Semi Detil skala 1:50.000 Kabupaten Batanghari 


\section{Pewilayahan Komoditas Pertanian}

Untuk mengetahui potensi sumberdaya lahan untuk pengembangan komoditas pertanian, dilakukan evaluasi lahan baik secara fisik maupun ekonomi dengan menggunakan parameter karakteristik lahan yang berpengaruhi terhadap produktivitas tanaman. Evaluasi lahan dilakukan dengan asumsi masukan (input) "sedang", yaitu dengan menerapkan teknologi petani yang ada saat ini (existing) dengan didukung oleh bantuan pemerintah seperti kredit permodalan untuk penyediaan sarana produksi dan teknik pengelolaan lahan, seperti pemupukan dan konservasi tanah (FAO, 1983). Dalam penilaian kesesuaian lahan, parameter kualitas lahan yang dipertimbangkan untuk dievaluasi lahannya dengan Tipe Penggunaan Lahan (TPL) input sedang adalah bahaya erosi (eh), media perakaran (rc), dan rejim suhu udara (tc), sedangkan ketersediaan air (wa), retensi hara (nr), dan ketersediaan hara (na) dipertimbangkan pada penilaian lahan input rendah. Dari parameter kualitas lahan tersebut, media perakaran, rejim suhu udara relatif lebih sulit untuk diatasi, dibandingkan dengan kualitas lahan lainnya.

Hasil pengolahan dengan program Modul Pewilayahan Komoditas (MPK) diperoleh 13 arahan pewilayahan komoditas pertanian sesuai dengan zona agroekologinya serta 4 pewilayahan non pertanian (Tabel 5 dan Gambar 3).

Berdasarkan arahan pewilayahan komoditas pertanian di atas ditetapkan 4 sistem pertanian atau alternatif pengembangan komoditas pertanian di Kabupaten Batanghari, sebagai berikut : (1) Pertanian lahan basah dengan luas (43.537. ha) dengan alternatif komoditas tanaman pangan (padi dan palawija), sayuran, (2) Pertanian lahan kering tanaman pangan dan hortikultura (162.120 ha), (3) Pertanian lahan kering tanaman tahunan berbasis tanaman pangan (273.566 ha), (4) Pertanian lahan kering tanaman tahunan/perkebunan (79.522 ha), dan (5) Hutan lahan basah dengan vegetasi alami (8.038.ha). 
Tabel 5. Arahan perwilayahhan komoditas pertanian Kabupaten Batanghari.

\begin{tabular}{|c|c|c|c|}
\hline \multirow{2}{*}{ Zona } & \multirow{2}{*}{ Sistem Pertanian/Alternatif Komoditas Pertanian } & \multicolumn{2}{|c|}{ Luas } \\
\hline & & $\mathrm{Ha}$ & $\%$ \\
\hline \multicolumn{4}{|c|}{ Pertanian Lahan basah } \\
\hline IV/Wr & Padi sawah & 19.260 & 3,40 \\
\hline IV/Wrh & padi sawah, jagung, kacang panjang, dan mentimun & 24.277 & 4,28 \\
\hline \multicolumn{4}{|c|}{ Pertanian Iahan Kering Tanaman Pangan dan Hortikultura } \\
\hline IV/Dfh-1 & $\begin{array}{l}\text { Jagung, kacang tanah, cabe, terong, kacang panjang, mentimun, pisang, } \\
\text { pepaya, duku, jeruk }\end{array}$ & 14.003 & 2,47 \\
\hline IV/Dfh-2 & Jagung, ubi kayu, ubi jalar, semangka, melon, pisang, nanas, pepaya & 29 & 0,01 \\
\hline IV/Dfh-3 & $\begin{array}{l}\text { Jagung, kacang tanah, ubi kayu, cabe, terung, kacang } \\
\text { panjang,mentimun,nanas, pisang,pepaya }\end{array}$ & 34.386 & 6,07 \\
\hline IV/Dfeh-4 & $\begin{array}{l}\text { Padi gogo, jagung, kacang tanah, ubi kayu, cabe, terung, kacang panjang, } \\
\text { mentimun, nanas, pisang, pepaya, kelapa sawit }\end{array}$ & 113.702 & 20,06 \\
\hline \multicolumn{4}{|c|}{ Pertanian Lahan Kering, Tanaman Tahunan Berbasis Tanaman Pangan } \\
\hline III/Defh-1 & Karet, kelapa sawit, kopi, durian, duku, manggis, padi gogo, jagung & 246.988 & 43,58 \\
\hline III/Defh-2 & $\begin{array}{l}\text { Karet, kelapa sawit, kopi, durian, duku, manggis, padi gogo, jagung,kacang } \\
\text { tanah }\end{array}$ & 26.578 & 4,69 \\
\hline \multicolumn{4}{|c|}{ Pertanian Lahan Kering Tanaman Tahunan/Perkebunan } \\
\hline II/Deh & Karet, kelapa sawit, kopi, durian, duku, manggis & 79.522 & 14,03 \\
\hline \multicolumn{4}{|c|}{ Hutan Lahan Basah } \\
\hline IV/Wj & Vegetasi alami & 208 & 0,04 \\
\hline x3 & & 7.791 & 1,37 \\
\hline $\mathrm{x} 8$ & & 39 & 0,01 \\
\hline & JUMLAH & 566.782 & 100,00 \\
\hline
\end{tabular}




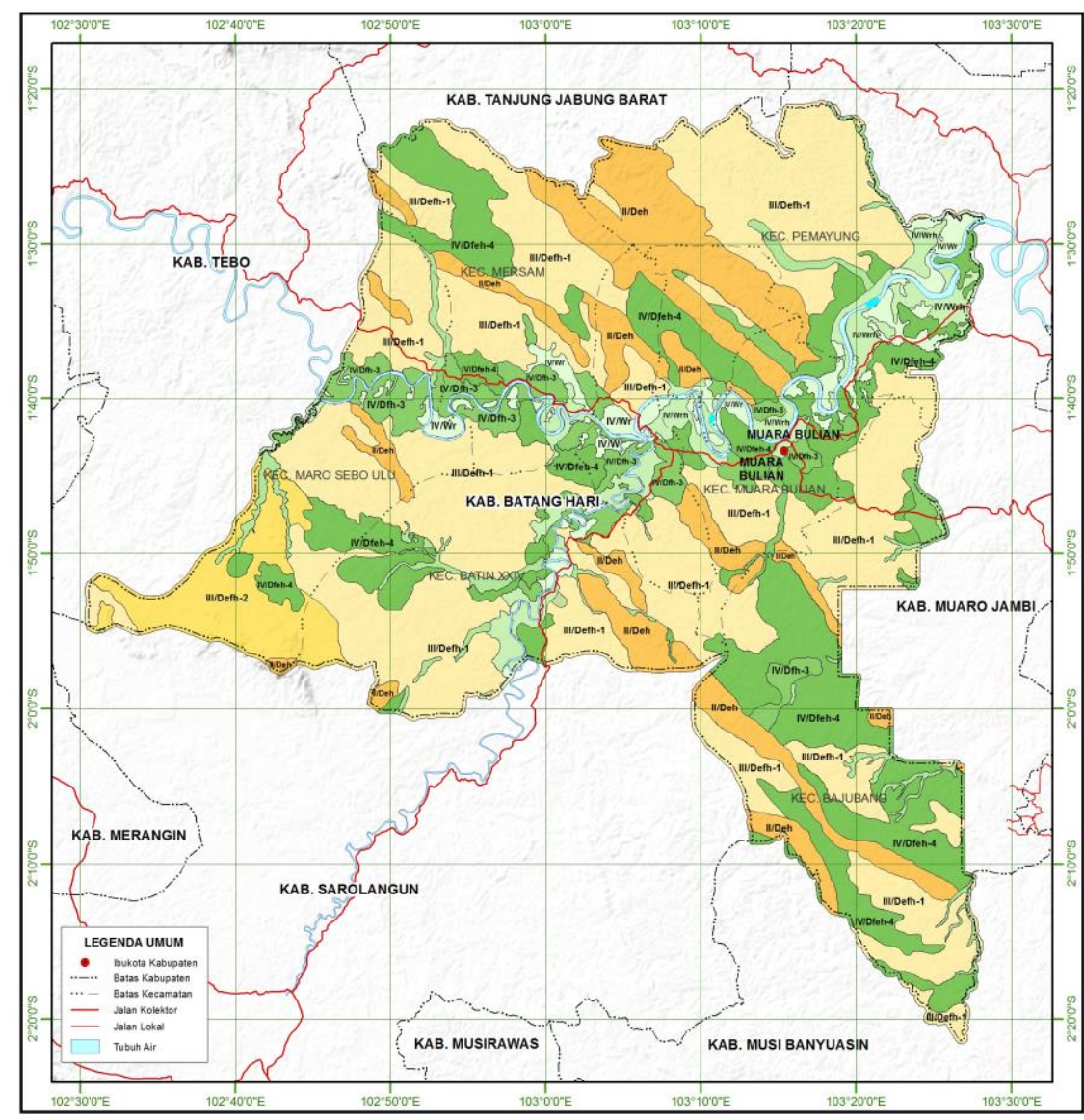

Gambar 3. Peta Pewilayahan Komoditas Pertanian Berdasarkan Zona Agroekologi Kabupaten Batanghari Skala 1:50.000. 


\section{KESIMPULAN}

1. Kabupaten Batanghari memiliki potensi yang cukup besar untuk pengembangan komoditas pertanian tanaman pangan, hortikultura dan perkebunan dimasa yang akan datang. Hal ini ditunjang oleh sumberdaya lahan dan iklim setempat.

2. Zona Agroklimat Kabupaten Batanghari termasuk ke dalam zona agroklimat $\mathrm{B}_{1}$. Curah hujan bulanan $206.87 \mathrm{~mm}$ dengan jumlah hari hujan 14.04 hari, suhu rata-rata bulanan $26.42^{\circ} \mathrm{C}$ dan Kelembaban $26.45 \%$. Curah hujan bulanan tertinggi diatas $200 \mathrm{~mm} / \mathrm{bulan}$, terjadi pada bulan November sampai April, sedangkan curah hujan bulanan di bawah 200 mm terjadi pada bulan Mei sampai Oktober.

3. Landform Kabupaten Batanghari dapat dikelompokkan dalam 3 group fisiografi utama yaitu Aluvial (A), Volkanik (V), dan Tektonik/Stuktural (T). Kabupaten Batanghari didominasi oleh bentuk wilayah bergelombang, lereng 8-15\% yang mencakup luasan $44,01 \%$ dari luas kabupaten.

4. Jenis tanah di Kabupaten Batanghari digolongkan ke dalam 4 ordo tanah, yaitu: Histosol, Inceptisols, Ultisols dan Oxisols. Pada tingkat yang lebih rendah (Grup) dibedakan menjadi Fluvaquents, Endoaquepts, Dystrudepts, Hapludults, Kandiudults, Kandiudox dan Hapludox.

5. Berdasarkan arahan pewilayahan komoditas pertanian ditetapkan 4 sistem pertanian, yaitu sistem pertanian lahan basah untuk tanaman padi sawah, palawija dan sayuran (Zona IV/Wr dan IV/Wrh), pertanian lahan kering tanaman pangan dan hortikultura (Zona IV/Dfh-1, IV/Dfh-2, IV/Dfh-3, dan IV/Dfeh-4); pertanian lahan kering, tanaman tahunan berbasis tanaman pangan (Zona III/Defh-1 dan III/Defh-2), pertanian lahan kering tanaman tahunan/perkebunan (ZonaII/Deh).

\section{Daftar Pustaka}

Amien, I. 2011. Menuju pertanian tangguh melalui pendekatan agroekologi. Orasi pengukuhan Profesor Riset Bidang Kesuburan Tanah. Badan Litbang Pertanian. Bogor, 7 April 2011. 45 hal.

Bachri, S., N. Suharta, A.B. Siswanto, dan Irawan. 2002. Modul Pewilayahan Komoditas, versi 1.2. Puslitbang Tanah dan Agroklimat, Badan Litbang Pertanian, Bogor

Bakosurtanal.1998. Peta topografi/rupabumi skala 1:25.000 Kabupaten Bima. Bakosurtanal. Jakarta.

Balai Penelitian Agroklimat dan Hidrologi, 2003. Atlas Sumberdaya Iklim Pertanian Indonesia Skala 1:1000.000. Bogor. 
Balai Penelitian Tanah. 2001. Petunjuk Teknis Penyusunan Peta Pewilayahan Komoditas Pertanian Berdasarkan Zona Agro Ekologi (ZAE) skala 1:50.000 (Model 1). Balai Penelitian Tanah, Puslitbangtanak Bogor.

Balai Penelitian Tanah. 2003. Pedoman pengamatan tanah. Edisi I. Pusat Penelitian dan Pengembangan Tanah dan Agroklimat, Bogor.

BBSDLP. 2011. Petunjuk Teknis Evaluasi Lahan untuk Komoditas Pertanian. Edisi Revisi 2011. Balai Besar Penelitian dan Pengembangan Sumberdaya Lahan Pertanian. Bogor

BBSDLP. 2014. Sumberdaya Lahan Pertanian Indonesia: Luas, penyebaran, dan potensi ketersediaan. Laporan Teknis No.1/BBSDLP/10/2014. Balai Besar Penelitian dan Pengembangan Sumberdaya Lahan Pertanian. Bogor.

BPS. 2016. Batanghari Dalam Angka Tahun 2016.

Eviati dan Sulaeman. 2012. Petunjuk Teknis Analisis Kimia Tanah, Tanaman, Air dan Pupuk. Edisi 2. Badan Litbang Pertanian. Kementerian Pertanian.

FAO. 1996. Agro-ecological zoning guidelines. Soil Bulletin 73. Soil Resources, Management and Conservation Service, FAO Land and Water Development Division, Rome.

F.A.O, 1983. Guidelines Land Evaluation for Rainfed Agriculture. Soil Bulletin No. 52. Soil Resources Management and Consevation Service Land and Water Development Division.

Hikmatullah, S. Ritung, Sukarman dan K. Nugroho. 2014. Petunjuk Teknis Survei dan Pemetaan Tanah Tingkat Semi Detail Skala 1:50.000. Balai Besar Penelitian dan Pengembangan Sumberdaya Lahan Pertanian (BBSDLP), Badan Penelitian dan Pengembangan Pertanian, Kementerian Pertanian. Bogor.

Kadariah. 1988. Evaluasi Proyek. Analisa Ekonomis. Ed. Ke-2. LPFE UI, Jakarta.

Las, I., A.K. Makarim, A. Hidayat, A. Syarifuddin, dan I. Mawan. 1990. Pewilayahan Agroekologi Utama Tanaman Indonesia. Puslitbangtan, Edisi Khusus, Pus/03/90.Bogor.

Oldeman L.R., Irsal L., and Muladi, 1979. Agroclimatic Map of Sumatra. Central Research Institute for Agriculture, Bogor.

Puslitbang Geologi. 1992. Peta geologi bersistem Indonesia lembar Sarolangun (0913) skala 1:250.000. Pusat Penelitian dan Pengembangan Geologi. Bandung. 
Puslitbang Geologi. 1994. Peta geologi bersistem Indonesia lembar Muara Bungo (0914) skala 1:250.000. Pusat Penelitian dan Pengembangan Geologi. Bandung.

Soil Survei Staff. 2014. Keys to Soil Taxonomy, $12^{\text {th }}$ ed. USDA-Natural Resources Conservation Service, Washington, DC. 